\section{J O U R A L O F}

French and Francophone Philosophy
REVUE DE LA

philosophie française et de langue française

\title{
Recent Work on Negritude
}

\section{Chike Jeffers}

Journal of French and Francophone Philosophy - Revue de la philosophie française et de langue française, Vol XXIV, No 2 (2016) 304-318.

\author{
Vol XXIV, No 2 (2016) \\ ISSN 1936-6280 (print) \\ ISSN 2155-1162 (online) \\ DOI $10.5195 /$ jffp. 2016.753 \\ www.jffp.org
}

\section{(c) EY-NC-No}

This work is licensed under a Creative Commons Attribution-Noncommercial-No Derivative Works 3.0 United States License.

\section{ULIS D-Sunt}

This journal is operated by the University Library System of the University of Pittsburgh as part of its D-Scribe Digital Publishing Program, and is co-sponsored by the University of Pittsburgh Press 


\title{
Recent Work on Negritude
}

\author{
Chike Jeffers
}

Dalhousie University

F. Bart Miller, Rethinking Négritude through Léon-Gontran Damas (Amsterdam: Rodopi, 2014).

Cheikh Thiam, Return to the Kingdom of Childhood: Re-Envisioning the Legacy and Philosophical Relevance of Negritude (Columbus, OH: The Ohio State University Press, 2014).

Carrie Noland, Voices of Negritude in Modernist Print: Aesthetic Subjectivity, Diaspora, and the Lyric Regime (New York: Columbia University Press, 2015).

Reiland Rabaka, The Negritude Movement: W.E.B. Du Bois, Leon Damas, Aime Césaire, Léopold Senghor, Frantz Fanon, and the Evolution of an Insurgent Idea (Lanham, MD: Lexington Books, 2015).

Gary Wilder, Freedom Time: Negritude, Decolonization, and the Future of the World (Durham, NC: Duke University Press, 2015).

The study of the artistic and intellectual movement known as Negritude is, in my view, among the most rewarding paths of research currently available to the student of Africana philosophy. This is so because of the challenging theoretical questions raised by the work of Negritude thinkers, whether one is reading the famous trio of Léopold Sédar Senghor of Senegal, Aimé Césaire of Martinique, and Léon-Gontran Damas of French Guiana, or others like the subjects of T. Denean Sharpley-Whiting's 2002 book, Negritude Women (i.e., Jane Nardal, Paulette Nardal, and Suzanne Césaire, all of Martinique). Understanding and evaluating their work requires thinking critically about how race relates to culture and how investment in black culture relates to anti-racist politics. What is culturally distinctive about black people? How compatible is pride in black culture with a cosmopolitan outlook that sees value in the intermixing of diverse cultures? Does a focus on the cultivation of cultural identity distract from or push forward the political struggles for social transformation needed to end racism? Questions like these are forced upon us by the texts of Negritude, along with methodological questions like how we ought to understand the relations 
between the philosophical prose, the celebrated poetry and other creative writing, and the activities while holding political office of the most famous Negritude thinkers.

If I am right about how rewarding the study of Negritude is, then it is our good fortune to be living in a time where scholarly interest in Negritude in the English-speaking world appears to be on the rise. Earlier in the present decade, Donna V. Jones critically engaged Negritude and its relationship to the thought of Henri Bergson in The Racial Discourses of Life Philosophy: Négritude, Vitalism, and Modernity (Columbia University Press, 2010), F. Abiola Irele collected his important writings on the subject in The Negritude Moment: Explorations in Francophone African and Caribbean Literature and Thought (Africa World Press, 2011), and John Patrick Walsh gave us Free and French in the Caribbean: Toussaint Louverture, Aimé Césaire, and Narratives of Loyal Opposition (Indiana University Press, 2013). Significant translations appeared, like my translation of Souleymane Bachir Diagne's book on Senghor, published as African Art as Philosophy: Senghor, Bergson and the Idea of Negritude (Seagull Books, 2011), and the collection of Suzanne Césaire's writings, The Great Camouflage: Writings of Dissent (1941-1945) (Wesleyan University Press, 2012), edited by Daniel Maximin and translated by Keith L. Walker. ${ }^{1}$

But if the early part of the decade brought a steady flow of texts, then the years 2014 and 2015 have delivered a veritable explosion. The five books under review were all published over the course of those two years. My intention in what follows is to discuss interpretive tendencies and the conflicts between them discernable in these books, to say something about what contribution each book makes to our understanding of Negritude, and to close with a focused examination of the treatment of Senghor in three of the books. How to make sense of Senghor and assess his continued relevance emerges as a particularly important challenge when reading the books under review.

\section{European or African?}

Saving the case of Senghor for later, the trend that stands out when reading these books, in my view, is a general concern about how intellectually European or African the Negritude thinkers were. In Carrie Noland's Voices of Negritude in Modernist Print, we are asked to consider the significance of Negritude poetry being a matter of printed texts in French rather than something primarily oral or written in languages or language varieties other than standard French. The Negritude poets are interpreted and evaluated as members of the "typosphere" - "that uniquely modern (post-Gutenberg) world in which paper and typeface are the matter of words" (1). Their publications, particularly those by Césaire and Damas, are further contextualized with reference to the wider array of modernist experiments 
undertaken by French poets at the time they were writing, often in the same journals in which some of their works were initially published. While recognizing the distinctive intention of Negritude poetry to articulate a certain black experience and identity, Noland emphasizes the medium they chose to accomplish this task in a way that encourages us to see these poets as deeply embedded in a European literary landscape. When discussing Damas, for example, she questions attempts to associate his style with the musical rhythms of Africa or the African diaspora and turns our attention instead to the textual rhythms of interwar socialist poetry in France (chapter $4)$.

We see something like the opposite move in Cheikh Thiam's Return to the Kingdom of Childhood and Reiland Rabaka's The Negritude Movement. Despite not including his name in its title, Thiam's book is focused completely on Senghor and aims to provide, with reference to Senghor's work, an "Afri-centered reading of the philosophy of Negritude" (6). Thiam claims that too many have dismissed Senghor's output as a mere "reaction to colonization" irrelevant to a postcolonial world, rather than recognizing it as a complex philosophical system worth our continued attention (5). He also argues, however, that those who have recognized its philosophical nature have failed to do justice to its African character. For example, the way that Jones and Diagne treat Bergson as foundational to Senghor's thought, thus privileging his connection to a European philosopher, means for Thiam that they have fallen short of "producing a truly decolonial reading of Negritude" (6). What is needed and what Thiam tries to achieve is a reading of Senghor's philosophy that focuses on the "African foundation of his methodology" and that demonstrates how his thought is "rooted in African realities" $(6,11)$.

The structure of Rabaka's book is indicative of his concern to place Negritude in an Africana rather than European genealogy of ideas. Following his preface, his introduction is entitled "Du Boisian Negritude: W.E.B. Du Bois, The Souls of Black Folk, and the Origins of the Negritude Notion" and then the first chapter is "Prelude to Negritude: The New Negro Movement, the Harlem Renaissance, and the Early Evolution of the Negritude Notion." The second, third, and fourth chapters are on Damasian, Cesairean, and Senghorian Negritude, respectively, while the fifth and final chapter, in what is bound to be a surprise for readers familiar with Africana thought, is entitled "Fanonian Negitude." I will not yet evaluate Rabaka's controversial proposal that Frantz Fanon, who is generally seen as one of Negritude's major critics, should be seen as in a way carrying the movement forward. The point, for now, is that, when looking at the genesis and impact of Negritude, Rabaka is concerned to highlight relationships of influence among black intellectuals, in opposition to what he perceives as a tendency to pay lopsided amounts of attention to white sources of inspiration. There exists, in his view, a "predisposition to read the Negritude Movement as a 
discursive derivation of the French intellectual tradition, especially French Marxism, surrealism, structuralism, existentialism, and phenomenology" (4). Without intending to deny its connections to French thought, Rabaka aims to disturb this predisposition and focus on Negritude's place in "the continental and diasporan African intellectual tradition - which is to say, the Africana intellectual tradition" (4).

F. Bart Miller's Rethinking Négritude through Léon-Gontran Damas, which provides readings of four of Damas' works, is arguably the exception to the trend I am discussing, as Miller is not concerned to reclaim Damas from others accused of either ignoring or overemphasizing his participation in European lineages of art and thought. A central theme of Miller's book is Damas' experimentation with different genres of writing, including lyric poetry, ethnographic essays, and the retelling of folktales, and while this leads him at times to talk of how Damas engages with and subverts European traditions (as in the case of ethnography), at other times it means talking of how Damas draws upon Afro-Caribbean traditions (as in the case of folktales). Miller says only a little about the influence of European writers on Damas, but neither does he say much about Africana influences beyond Damas' fellow creators of Negritude, Senghor and Césaire.

Gary Wilder's Freedom Time is, like Miller's book, not readily identifiable as on one side or the other of the debate, but this is not because it is an exception to the trend of intervening in the debate. Determining how exactly Negritude thinkers stand in relation to Europe has been a task that Wilder has explicitly pursued since his previous book, The French Imperial Nation-State: Negritude and Colonial Humanism between the Two World Wars (Duke University Press, 2005). Freedom Time can be seen as a sequel to The French Imperial Nation-State in a number of ways - for example, the earlier book focuses on the interwar period while the new book focuses on the postwar period (from 1945 to 1960). Viewed as a sequel, though, one of the most interesting aspects of Freedom Time is its shift away from the critical angle in The French Imperial Nation-State, in which Wilder argued that the evolving contradictions of the French colonial project led Negritude thinkers to articulate responses to colonialism that were impressively creative but also beset by contradictions of their own. Freedom Time, by contrast, invites us to reflect on the coherence, insight, and exciting potential of the visions for transforming France and its empire that Senghor and Césaire, in particular, elaborated in the postwar period.

Thus, in Freedom Time, Wilder intervenes in the debate about how European or African/Africana the Negritude thinkers are by making a powerful case for their transcendence of this distinction, at least during this particular period. Senghor and Césaire sought to end colonialism, Wilder argues, by proposing forms of political integration that would "reconstitute France itself, by quietly exploding the existing national state from within" (2). They refused to assume that decolonization for Africa and the Caribbean 
required independence from France, envisioning instead possibilities such as "a decentralized democratic federation that would include former colonies as freely associated member states," thus rupturing the "presumptive unity of culture, nationality, and citizenship" in France (2). As Wilder presents them, what these two Negritude thinkers managed to conceive and make plausible at that time was the possibility of allegiance to Europe and allegiance to a liberated Africa and African diaspora being one and the same thing.

Wilder clearly offers the most striking answer to the question of how intellectually European or African the Negritude thinkers are, which does not, of course, mean that he is therefore right while the other authors who take a position are wrong. Indeed, I think there is something right in what each author says, along with, in each case, the danger of taking the point too far. Noland is right that we should avoid treating the intention on the part of Negritude poets to illustrate and explore black difference as if it implies sharp separation from their French literary milieu. On the other hand, in order not to take this point too far, we should avoid downplaying the significance of that intention and its indication of real cultural difference undiminished by the choice to write in French, undertake certain experiments of form, and publish in modernist venues. Thiam and Rabaka are thus right to emphasize the emergence of Negritude out of Africana experiences and intellectual traditions. On the other hand, this point can also be pushed too far, as no obstinate preference for Africana contextualization will change the reality that Negritude writing is deeply influenced by European art and thought.

Where does this leave us? Should we simply say that Negritude is equally a product of both Africa and Europe? This is too easy and the claim of equal amounts is especially suspicious. How are we quantifying the elements involved? Even if the equality claim is fine, is there no tension or friction to be accounted for here, given that Negritude is a movement championing African cultural identity in response to European racism? Are there no differences between the various Negritude thinkers to be acknowledged when weighing European versus African cultural formation? The simple answer of saying "it's both" is true but unsatisfying. Any worthwhile attempt to address Negritude's cultural roots must say and substantiate what "both" looks like in this case. This is, as a matter of fact, what makes Wilder's Freedom Time not merely striking but convincing and worthy of high praise. It is an eye-opening study of two thinkers and political actors during a particular period, concentrating on a particular topic (the political relationship of postwar France to its colonies in Africa and the Caribbean), featuring careful analysis of ideas expressed in speeches, essays, and creative works, and charting the evolution of those ideas over the course of the period. It is no mere assertion of "both." 


\section{General Comments}

Let me now move from this specific theme to discussing what contributions in general these five books make to our understanding of Negritude. My positive estimation of Wilder's book has been made evident above, but let me be even clearer: Freedom Time is a fantastic work of political theory and one of the most original and insightful pieces of scholarship on Negritude I have read. Its historical narrative unfolds through an effective movement back and forth between the two Negritude thinkers covered: chapters 2, 5 , and 7 focus on Césaire and Martinique while chapters 3, 6, and 8 focus on Senghor and French West Africa. Chapters 1 and 9 introduce and conclude the book, respectively, and then there is chapter 4, a transitional chapter that includes discussions of, among other things, Jean-Paul Sartre on the 1944 liberation of Paris, Hannah Arendt on freedom, Albert Camus on the possibility of international democracy, Simone Weil on what France should do with its colonies, the postwar activities of Charles de Gaulle, and, finally, Immanuel Kant, Guiseppe Mazzini, and Pierre-Joseph Proudhon on federalism and cosmopolitanism. Ideas are explained in relation to their historical context and Wilder usefully places the Negritude thinkers into this network of ideas - a network not primarily of influence, to be clear, but rather of shared themes and of parallel relations to historical moments. The depth of theoretical engagement and parade of information may make this a slow read for some, but it is a worthwhile task.

Thiam's Return to the Kingdom of Childhood is an important book because it is, if I am not mistaken, the first book written in English whose self-conscious aim is the recognition and interpretation of Senghor as a systematic philosopher. It is worth noting, by the way, that Thiam was trained in comparative literature, Wilder in anthropology and history, and Rabaka in African American Studies, but all three have given us books that directly address the philosophical contributions of Negritude thinkers and prepare the way for professional philosophers to engage with them. Thiam's book is a passionate and creative plea for taking Senghor seriously as a theorist of race, time, and epistemology. Thiam demonstrates a thorough knowledge of Senghor's oeuvre, both prose and poetry. There are moments when he sheds new light on even the most famous of works by Senghor, such as the intriguing interpretation in the book's third chapter of Senghor's iconic poem, "Femme noire," as a celebration of cultural mixture (85-86).

While Thiam can be credited with proposing many intriguing interpretations, though, some of his conceptual moves are unclear in ways that make it hard to accept his proposals. The book's second chapter, "Negritude, Epistemology, and African Vitalism," begins by identifying Bergson's theory of duration as a "pre-condition" of Senghor's philosophy, which is confusing given his complaint about Jones and Diagne's emphasis on Bergson, mentioned above (38). This, however, is a minor complaint about order of presentation, as the final sections of the chapter do useful 
work in showing how we might think of Senghor's views as rooted, first and foremost, in African traditions. What is more severely confusing are the notions of time and race that Thiam introduces here. He tells us that Senghor develops a "fluid understanding of time," one which moves away from "a common separation of past, present, and future to the conception of time as the constantly becoming present ceaselessly reborn" (40). What does this mean? As he explores the depiction of time in one of Senghor's poems ("Que $\mathrm{m}^{\prime}$ accompagnent koras et balafong"), it is difficult to tell if he is just making plausible points about how different times may lose distinction and order in one's memory or asking us to consider bolder, more dubious metaphysical claims about past, present, and future being indistinguishable.

Connecting time with race and culture, Thiam claims: "Following Senghor's logic, one can state that even if the diverse cultures of continental Africa or of the Diaspora are bound to constantly become other, they remain African in that their present is inseparable from their past, since pastpresent-future participate in the same movement of becoming" (44). There may be plausible ways of treating past and present as inseparable (as opposed to indistinguishable), but Thiam does not clarify this thought in ways that help us make sense of Senghor. He claims that, on Senghor's view, the inseparability of past and present shows that there is "no reason to fear acculturation and no need to attempt to retrieve supposedly lost African roots" (45). Senghor does not, in fact, view the loss of culture as something we need not fear and the quotation from his essay, "What the Black Man Contributes," that Thiam treats as evidence for his interpretation makes the sociohistorical claim that slavery acted as a compensating force vis-à-vis the change in environment and miscegenation with regard to the retention of African culture in the Americas. That is not a statement about the nature of time but about the contingencies of history.

I will have more to say about Thiam on race below. For now, let me move to discussing the importance of Rabaka's The Negritude Movement. The genealogy Rabaka constructs is, in my view, usefully accurate in its identification of the antecedents of Negritude, thought-provoking in its ordering of the Negritude thinkers, and brilliantly provocative in naming Fanon as Negritude's heir. In my dissertation, The Black Gift: Cultural Nationalism and Cosmopolitanism in Africana Philosophy (Northwestern University, 2010), I too sought to highlight the lineage of thought connecting Du Bois and Negritude, so I am happy to see Rabaka demanding recognition of Du Bois' significance in relation to the movement. ${ }^{2}$ The chapter on the Harlem Renaissance develops our understanding of this lineage in interesting ways - for example, by insisting on distinguishing the New Negro movement, of which Du Bois is said to be the "maestro," from the Harlem Renaissance, with Alain Locke as "ringleader" $(41,42)$.

It is a significant contribution of his book that Rabaka moves next to bring Damas to centre-stage. Damas is, as Rabaka notes, "routinely 
marginalized in literary and intellectual histories of Negritude" in comparison with Senghor and Césaire (89). As Rabaka points out, though, Damas played a major role in making connections with the Harlem Renaissance and he was the first of the trio to publish books, whether poetry (1937's Pigments) or prose (1938's Retour de Guyane). These factors and others lead Rabaka to boldly suggest that we start viewing Damas as the most appropriate "point of departure for those interested in the history, interpretation, and criticism of the Negritude Movement" (89). Even as someone who ultimately remains more interested in the work of Senghor and Césaire, I find the case Rabaka makes for centering Damas impressive. ${ }^{3}$ Also extremely useful is Rabaka's invitation in the chapter on Damas to consider the influence of what is known as the Haitian Renaissance on Negritude, with a particular focus on the influence of Jean Price-Mars on Damas.

What should we make of Rabaka's contention that Fanon may be seen as in some sense a part of the Negritude movement? This thesis is provocative given that Fanon appears critical of Negritude in both of his major works (Black Skin White Masks and The Wretched of the Earth) but brilliant as it rests on a simple and plausible argument. Sartre is commonly taken to be an important influence on Fanon and traces of this influence are part of why we think of Fanon as an important existentialist thinker. It is also the case, however, that Fanon appears critical at times of Sartre including, most famously, with respect to Sartre's treatment of Negritude. Rabaka asks: "If, indeed, Fanon's critique of Sartre is not interpreted as a complete discursive disavowal, why then is his selective critique of Cesaire, and the Negritude Movement more generally speaking, routinely taken as an outright repudiation of each and every aspect of Negritude?" (254). Evidence of the influence of Césaire, especially, on Fanon's thought is not hard to discern, which is unsurprising, as it should be remembered, after all, that Fanon had Césaire as a teacher in Martinique. Rabaka concludes that Fanon should be seen as Negritude's "most illustrious intellectual heir" (36).

This novel approach to Fanon and Negritude is insightful, in my view, although once we go beyond the simple argument above to consider all that Rabaka says in his chapter on Fanon, the case he is making turns out to be weaker than it seemed. The problem, as I see it, lies in Rabaka's treatment of that memorable part of the fifth chapter of Black Skin White Masks where Fanon discusses "Black Orpheus," Sartre's introductory essay to an anthology of poetry edited by Senghor. This essay did much to popularize the term "Negritude," but Fanon describes experiencing Sartre's essay as a fatal blow to the activity of young black poets because of its closing depiction of Negritude as stage in a dialectical process in which the thesis is the affirmation of white supremacy, Negritude is the antithesis, and the synthesis is the achievement of a society without race. Negritude is thus, according to Sartre, dedicated to its own destruction. Rabaka treats Fanon as 
standing up for Negritude in reaction to paternalistic racism on Sartre's part. He writes: "Fanon felt that Sartre missed the main point of Negritude, which was to remind "Negroes" that they were Africans before they were racially colonized and coerced into accepting their "Negrohood"" (282).

This interpretation is puzzling for a number of reasons, starting with the idea that it could be the main point of the movement known as Negritude to distinguish Negrohood from being African and uphold the latter over the former ("Negrohood" is, in fact, a plausible way to translate the term "Négritude"!). Beyond this, the problem is that Fanon's position here is a slippery one and Rabaka fails to communicate this. What does it mean when Fanon says that "I needed to lose myself totally in negritude... I needed not to know" ?4 That Sartre "shattered my last illusion"?5 There is, apparently, criticism of Sartre here as well as, at least apparently, an admission that Sartre was somehow telling the truth about what Negritude is. My reading of Fanon's criticism of Sartre is that, at least with respect to the question of the nature of Negritude, there is no criticism here at all but rather simply an expression of anguish at what Fanon takes to be the failure of Negritude to deliver what it appeared to promise: an autonomous black identity. As I have admitted the slippery nature of the text, I accept that this proposed reading is controversial. My biggest complaint about Rabaka's reading, though, is that he does nothing to show how what he says can be reconciled with the concluding chapter of Black Skin White Masks, in which Fanon seems to radically reject not just Negritude but all forms of black pride.

Let me now move from Wilder, Thiam, and Rabaka to the books of literary criticism, which I am somewhat less well-positioned to evaluate given my training as a philosopher rather than literary critic. I take the general position, however, that analyses by literary critics of Negritude poetry and other creative writing are useful for those with philosophical interests in Negritude, given the shared goal of making sense of what is going on in the texts produced by the movement. Noland's Voices of Negritude in Modernist Print is quite an impressive contribution to our understanding of Negritude in light of its theoretical sophistication and its very close readings of the works it considers. Noland is spectacularly attentive to words: how they sound, their morphological relations, the way they are organized on the page, their connotations, and how any of these features may relate to any of the others.

Where I would criticize the book is, as referenced before, in relation to the question of how much significance we accord to the intention of Negritude poets to offer us something distinctively black in their work. I sometimes wondered, while reading, whether it might even be appropriate to describe Noland's approach as Schuylerian. What I have in mind is the critical position on the Harlem Renaissance that George Schuyler takes in his 1926 essay, "The Negro-Art Hokum," published in The Nation. He dismisses the idea of distinctively black art, arguing that black people, wherever they 
are, make art in accordance with their cultural milieu: "As for the literature, painting, and sculpture of Aframericans - such as there is - it is identical in kind with the literature, painting, and sculpture of white Americans; that is, it shows more or less evidence of European influence." 6 Langston Hughes, the great Harlem Renaissance poet, responded to Schuyler in the same magazine with an essay entitled "The Negro Artist and the Racial Mountain." As Rabaka points out, the Negritude thinkers later acknowledged this particular essay by Hughes as massively influential on their thinking (143). Hughes defends the goal of seeking to create distinctively black art: "it is the duty of the younger Negro artist... to change through the force of his art that old whispering "I want to be white," hidden in the aspirations of his people, to "Why should I want to be white? I am a Negro - and beautiful!"'"7

It is interesting that, in her third chapter, Noland discusses the influence of Hughes on Damas, particularly with regard to the typographical arrangement of words on the page, and she offers a close reading of Hughes' 1934 poem, "Cubes" (111-116). Even here, though, she is concerned to point out that the "staircase" technique that Hughes and Damas employ has "a long history in French lyric poetry" and that, despite the fact that "critics who have noted the use of patterned lineation in Hughes or Damas have consistently related such patterning to the putative musicality of their poems," what Hughes gives us in "Cubes" is a distinctly modernist reflection on the aesthetics of fragmentation pursued by the cubists $(111,115)$. I would not dispute Noland's reading of "Cubes," but note that it is important to Hughes that many of his poems involve attempts to "grasp and hold some of the meanings and rhythm of jazz" because he takes jazz to be "one of the inherent expressions of Negro life in America." 8 worry that Noland does not do enough to help us understand intentions of this sort and to discern the result, whether in Hughes or the Negritude poets.

Miller's Rethinking Négritude through Léon-Gontran Damas feels relatively simple and straightforward when juxtaposed with the theoretical ambition and density of Noland's book, which makes it both more accessible as well as less often awe-inspiring. (Note, by the way, that one important way in which it is decidedly not accessible is that none of the quotations from Damas or from any other French source are translated into English, so those who cannot read French are out of luck.) The book's first chapter offers readings of selected poems in Pigments. These readings are sometimes insightful, although I found the terminology of adopting, adapting, and becoming adept in relation to colonialism that Miller takes from Peter Barry to be more often confusing than illuminating. The second chapter is a useful tour through many of the topics that Damas covers in Retour de Guyane, a unique critique of colonial governance of French Guiana. One oddity of the chapter, though, is Miller's treatment of Damas' remarks on the "rural man" 
as remarks on "maroon descendants" or "the maroon population" $(132,133)$. I could not find the textual basis for this questionable identification. The third chapter is on Veillées noires, a collection of folktales. It presents a welcome opportunity to reflect on how the transmission of oral tradition can involve authorial choices that represent anti-colonial struggle. Finally, the last chapter is on Damas' long poem, Black-Label, and it is an excellent discussion of a fascinating work.

\section{On Senghor}

I will now move from the general back to the specific in order to discuss how Senghor is portrayed in the books in which he is treated as a central topic - that is, in Rabaka, Thiam, and Wilder's books. ${ }^{9}$ Let me first note a striking similarity in the ways that Rabaka and Thiam bring their books to a close. Thiam's fourth chapter is entitled "Negritude is Not Dead!" and it is followed by a Conclusion, which ends with Thiam saying: "No, Negritude is not dead. It is more relevant now than ever" (121). Meanwhile, Rabaka ends his chapter on Fanon and his book as a whole with an italicized chant: "Long live the spirit of the Negritude Movement! Damasian Negritude lives! Cesairean Negritude lives! Senghorian Negritude lives! Fanonism lives!" (332). This concern with Negritude not being dead but rather continuing to live is obviously a response to widespread understandings of Negritude as being, in fact, an extinguished thing of the past. Among the reasons Negritude is seen this way is a perception of Senghor as having done the most to define Negritude and as having, in doing so, promoted a preposterous form of racial essentialism that has no place in the theorizing of black identity, culture, and politics today. After all, this is the man famous for writing "Emotion is Negro, as reason is Hellenic," thus seemingly treating reason as culturally foreign to black people!10 When people like Thiam and Rabaka claim that Negritude is alive and well, then, an important question to ask is what they are proposing we do with Senghor. Are we striving to eradicate or at least complicate his reputation as a problematic essentialist whose practical relevance to current thought is nil?

While Rabaka is kind enough to include Senghor in his closing chant, the real answer to that question for him is no. Senghor as depicted in Rabaka's fourth chapter is by far the least respectable member of the Negritude movement. According to Rabaka, "[i]n sidestepping the political by collapsing it into the cultural, Senghorian Negritude connects with and in some senses becomes an imperialist agent for colonial policy, colonial anthropology, and colonial ethnology" (203). Senghor's views are described as "politically impotent, insult-embracing, racism-accepting and colonialism-condoning" (210). His theory of African socialism is decried as insufficiently African and insufficiently socialist (214). In spite of what Rabaka has to say concerning Sartre's wrongness about Negritude in the 
chapter on Fanon, he concludes in the chapter on Senghor that Senghorian Negritude was "born only to die, because it cannot and does not exist outside of the Manichaean world and the imperial machinations of Europe" (209).

Rabaka is, in my view, often unfair to Senghor and he sometimes displays a stunning insensitivity to the ways in which Senghor set out to construct a liberatory African cultural perspective. For example, Rabaka claims that Senghor "exhibits a hyper-consciousness of French and other Eurocentric views and values, and especially in terms of interpreting and articulating African history and culture, and... rarely reverses this practice and employs African views and values as a rubric for interpreting French and other European history and culture" (211). Then, soon thereafter, Rabaka describes Senghor's famous claim about how the African encounters the object and does not assimilate it but assimilates himself into it. Rabaka argues that if the object is European culture, then Senghor is guilty of asking Africans to assimilate themselves into cultures "whose thought and behavior have historically been horribly xenophobic and jingoistic and, even more, downright brutal and genocidal, toward non-European cultures" (212). But one need not even be considering endorsing Senghor's distinction between black and white ways of knowing as a factual distinction to notice that his description of the white way of knowing - analyzing, taking apart, assimilating the object, and using it for one's own ends - is meant to evoke precisely the colonial exploitation and cultural oppression of non-Europeans that Rabaka thinks Senghor is failing to criticize! Indeed, it is central to Senghor's thought that European culture can and must be critically interpreted and evaluated from an African point of view.

Some weaknesses of Rabaka's critical engagement with Senghor derive from strange choices in terms of the textual basis for the engagement. Rabaka quotes on a number of occasions from a 1996 anthology of African philosophy (Parker English and Kibujjo Kalumba's African Philosophy: A Classical Approach) in which the editors pull selections from the popular 1965 collection of Senghor's writings, Prose and Poetry. Those familiar with the latter know that the prose section contains excerpts arranged thematically rather than chronologically and, in the 1996 anthology that Rabaka uses, one furthermore loses the dates and citations of original texts that one finds in Prose and Poetry. I find it irresponsible to encourage scholarly engagement with Senghor through reliance on such a text.

Not even this inadvisable choice, however, can explain Rabaka's strikingly bizarre claim that, in the 1960s, Senghor began to talk often of Africanite rather than Negritude because he "discovered that whites did not like the term Negritude and, in his incessant efforts to appeal to whites... he began using Negritude and Africanité, in most instances, synonymously depending on his intended audience" (207). This is utter nonsense, easily disproven through reading even just the titles of Senghor's speeches over the 
years, and Rabaka's reference to the 1996 anthology naturally does nothing to support it. Rather, what is excerpted there - from a passage in Prose and Poetry that comes from a 1961 speech at the Ghanaian parliament unpublished outside of Prose and Poetry - makes it clear that Negritude is but one part of "Africanity," which Senghor conceptualized as the values of the continent as a whole, not just black Africa. ${ }^{11}$

Suffering through such problems in Rabaka's book, one may find Thiam's better knowledge of Senghor's work soothing and one may be open-minded with regard to his project of showing how wrong it is to dismiss Senghor as a problematic essentialist. Unfortunately, I think what we find in Thiam is the opposite problem: rather than being unfair, Thiam is too nice to Senghor. According to Thiam, "Senghor's conception of race is based on the postulation that although the existence of biological race is questionable, cultures do exist" (46). The claim that culture is central to Senghor's understanding of race is right, obviously, but the idea that he takes the biological reality of race to be questionable is wrong, as he demonstrates his belief in a fundamentally important biological component to race from early in his work all the way to his 1988 book, Ce que je crois: Négritude, Francité, et Civilisation de l'Universel (the book features a chapter entitled "From Biology to African Culture"!). Thiam attempts to treat culture and biology as disconnected in relation to race in a way that it seems clear Senghor would not accept.

This faulty approach to Senghor on race leads in the book's fourth chapter to a seriously problematic discussion of how we might relate $\mathrm{Du}$ Bois and Senghor. Thiam claims that Senghor's Negritude "corrects" Du Bois (94). The first basis for the claim is a surprising treatment of Du Bois' notion of double consciousness as somehow tied to the same biological essentialism one can find in the work of Count Gobineau. It is not my view that $\mathrm{Du}$ Bois avoids racial essentialism completely, but the idea of twoness that Thiam targets is definitely not a clear instance of him falling into this problem and Thiam makes no convincing case for seeing it as such. The second basis for the claim is the assertion that Senghor's concept of time "makes possible an understanding of mixture as fundamental to the very being of races" (98). I have already pointed out that the conception of time Thiam is evoking is mysterious. What is newly problematic here is the fact that Thiam never explains how the idea of mixture can be understood apart from the idea of a combination of things which might be recognized as somehow distinct and so his criticism that $\mathrm{Du}$ Bois fails to understand races as "originally mixed" seems incoherent (99). Thiam holds that Senghor can reveal for us the way that the Du Boisian idea of twoness is based on the "ontological mistake" of "the imagined possibility of separating the past from the present and therefore precolonial identity from postcolonial hybridity" (100). I can think of no way to read this claim that makes it simultaneously metaphysically plausible in its conception of time, 
historically plausible in its conception of African American identity, and interpretively plausible in its reading of Du Bois.

In Rabaka and Thiam, then, we have two diametrically opposed attempts to deal with the importance of Senghor and both of them fail. What can we learn from these failures? One obvious lesson is that doing justice to Senghor requires a fair account of his emancipatory intentions but also a fair account of his essentializing flaws. I think one is learning the wrong lesson, however, if one views these two failures as completely on a par. We have behind us a long history of Senghor being dismissed as irredeemably flawed. It is therefore unclear to me why we should expect to get much out of further consideration of Senghor if criticisms are not at least balanced and better yet exceeded by efforts of the type Thiam is making - that is, efforts to identify the value in continuing to read Senghor and his ability to speak to our current context.

This is certainly part of the value of Wilder's treatment of Senghor. Freedom Time exposes Senghor's brilliance as a political thinker in a way that can usefully be read as responding to some of Rabaka's criticisms (in advance, as Wilder's book was published first!) and, shockingly, also to Thiam, who wrongfully concedes to critics that "Senghor has never seriously engaged the political question of decolonization" (23). The last chapter of Freedom Time includes a sober reflection on whether present day conditions vindicate Senghor's ideas from 1940s and 1950s about how territorial nationalism was bound to fail and how self-determination without state sovereignty was preferable. Wilder writes: “Following his imagined framework, Africans sans papiers in metropolitan France would not be foreigners demanding hospitality but citizens whose rights of mobility, family reunification, social security, and political participation were legally protected" (244). Wilder is critical as well, though, constantly reminding us that, in talking about the ideas of Senghor and Césaire as missed opportunities, he is not saying that they had everything worked out and that things would have necessarily gone as envisioned. One criticism that stands out for me: "Although [Senghor] argued that this democratic federation would be consonant with other forms of solidarity, such as pan-Africanism and socialist internationalism, and despite his interest in federating autonomous states within West Africa, he did not work out the mediations between these distinct levels of African political identification" (164).

In any case, Freedom Time is a study of but one aspect of Negritude thought and activity during a particular period. There is so much more work to be done, on Negritude in general and on Senghor's thought over the course of his lifetime. Like Rabaka and Thiam, I too believe that Negritude is not dead, that Negritude lives on, that Africana philosophy is richer when the significance of this movement is recognized, appreciated, and explored. I am therefore grateful for the way that this flurry of recent books testifies to its vitality. 
1 See my review of the latter in Vol. XXI, No. 1 (2013) of this journal.

2 Oddly, though, Rabaka quotes at one point in the chapter (p. 31) from Senghor's 1971 lecture, "Problématique de la Négritude," but the passage he quotes does not mention Du Bois and he never quotes this remarkable characterization of Du Bois' importance from that lecture: "One must always begin with W.E.B. Du Bois, who was truly "the father of the Negritude movement," as Lilyan Kesteloot has written, because he was the first mind to think it in its totality and specificity, its aspects and its purpose, its objectives and its means." Senghor, Liberté 3: Négritude et Civilisation de l'Universel (Paris: Éditions du Seuil, 1977), 274. Translation mine.

${ }^{3}$ When looked at from the perspective Rabaka gives us, it is curious that Damas is so absent from Wilder's Freedom Time, especially since he received extensive coverage in The French Imperial Nation-State. As Wilder notes, Damas served for some years in the French National Assembly along with Senghor and Césaire during the postwar period (275n3). Did he not weigh in at all on the questions of political transformation with which Freedom Time is concerned?

${ }^{4}$ Frantz Fanon, Black Skin, White Masks, trans. Richard Philcox (New York: Grove Press, 2008), $113-$ 114.

5 Ibid., 116.

${ }^{6}$ George S. Schuyler, "The Negro-Art Hokum," in Winston Napier, ed., African American Literary Theory: A Reader (New York: New York University Press, 2000), 25.

${ }^{7}$ Langston Hughes, “The Negro Artist and the Racial Mountain," in Napier, 30.

8 Ibid., 29, 30.

${ }^{9}$ It is interesting to note that, for each of the three famous founders of Negritude, three of the books under review focus on that figure. I have just mentioned those with a focus on Senghor; for Césaire, see Noland, Rabaka, and Wilder; and, for Damas, see Miller, Noland, and Rabaka.

10 Senghor, "What the Black Man Contributes," trans. Mary Beth Mader, in Robert Bernasconi, ed., Race and Racism in Continental Philosophy (Bloomington, IN: Indiana University Press, 2003), 288.

11 Senghor, Prose and Poetry, ed. John Reed and Clive Wake (London: Heinemann, 1965), 97. 